\title{
Pharmacognostical Standardization of Goraksha pods: an important Nutritive and antidiabetic Plant
}

\author{
Shantha Thirumalai Ramasheshan ${ }^{1 *}$, Patchaimal Pitchaiah', Prathapa Reddy Maramreddy', Vandana Bharti', \\ Kishore Kumar Ramakrishana', Venkateshwarlu Gaddam, Devesh Tewari ${ }^{2}$, Anupam Kumar Mangal' ${ }^{2}$, Madan Mohan Padhi², \\ Kartar Singh Dhiman² \\ Regional Ayurveda Research Institute for Metabolic Disorders (CCRAS, Min. of AYUSH) Ashoka pillar, Jayanagar, Bengaluru-560011, INDIA. \\ ${ }^{2}$ Central Council for Research in Ayurvedic Sciences, Ministry of AYUSH, Govt. of India, Janakpuri, New Delhi-110058, INDIA.
}

\begin{abstract}
Objective: Goraksha or cluster beans are an annual legume found throughout India. It is also extensively cultivated for its pods used as vegetable for its high nutritive value, antidiabetic properties and for the source of guargum. Methods: Macroscopy, microscopy, powder microscopy, histochemical studies and preliminary phytochemical studies on the pods of Goraksha has been carried out highlighting its importance along with important diagnostic characters, which will help in the identification of pods both in fresh form as well as in dry form. Results: Study revealed presence of distantly arranged elongated uniseriate warty trichomes in the outer most layer of epidermis, presence of stone cells, simple starch grains and very small calcium oxalate crystals in the hypodermal region. Presence of unevenly thickened row of palisade layer of macro sclereids in the outer most layer of cotyledon region. Phytochemical studies revealed the presence of alkaloids carbohydrates, phenols, proteins, saponins, starch, steroids, and tannins.
\end{abstract}

Conclusion: The pharmacognostical standardization revealed the presence of various specific characters which are important for the identification of the genuine pods of Cyamopsis tetragonoloba (L.) Taub.

Key words: Cluster beans, Goraksha, Pharmacognosy, Pods. Histochemical studies.

Corresponding author: Dr. ShanthaThirumalai Ramaseshan, Department of Drug Standardization Research Unit, Research Officer (Botany), Regional Ayurveda Research Institute for Metabolic Disorders, (CCRAS, Ministry of AYUSH, Govt. of India), Ashoka pillar, Jayanagar, Bengaluru- 560011, INDIA.

Phone no: 91- 9986365762

Email: shanthatr57@gmail.com DOI : 10.5530/pj.2016.5.2

\section{INTRODUCTION}

Cyamopsis tetragonoloba (L.) Taub. is sold in the name of Cluster beans and also known as Goraksha/Dridhabija (in Sanskrit) and Guar (in Hindi) in the local market of southern India. The botanical synonyms of Goraksha are C. Psoralioides (Lamk.) DC.; Psoralea tetragonoloba L. belonging to the family Fabaceae, under Sub family Papilionaceae. It is a moderate sized annual herb found throughout India as a cultivar for its pods and for the source of vegetable, seed-gum, forage and green manure. The stem is grooved; leaves are generally 3 -foliolate, sometimes simple; leaflets are elliptic with hair on both sides. Flowers are small, white or purple in color, typically papilionaceous, 6-3 flowers in axillary with close racemes. The pods are linear, stiff, erect clusters with double ridge compression on dorsal side and single ridge below. The tender green pods are popular vegetable in many parts of our country. ${ }^{1}$ The plant is recognized for its food price and possess different nutrients like proteins, fat, fibre, carbohydrates, minerals like calcium, phosphorus \& iron, fluoride, zinc, molybdenum, manganese, copper cobalt etc; vitamins like thiamine, riboflavin, niacin, vitamin $\mathrm{C}$, carotene, $\beta$-carotene, folic acid, ascorbic acid nicotinic acid etc.; amino acids like methionine, cystine, trptophan, valine, arginine, aspartic acid etc.; polyphenols like kaempferol, quercetin, chrysene, 1,2,5,6-dibenzanthracene etc. and globulin. ${ }^{1,2}$ The plant is traditionally used as vegetable, improves appetite and removes biliousness and night blindness. ${ }^{3}$ Different properties in Ayurveda are described in the name of Goraksha such as Rasa (Taste): madhura (Sweet); Guna (Properties): guru, ruksha, sara; Doshakarma: kaphavatavardhaka, pittanasaka; Karma (Action): ruchikara, balya. ${ }^{4}$ Goraksha exhibited different therapeutic activities such as anti hypercholesterolaemic, ${ }^{5}$ anti helminthic, ${ }^{6}$ hypolipidemic and hyoglycemic activity, ${ }^{7,8}$ antiulcer and cytoprotective activity. ${ }^{9}$ The pods of this plant have been recommended in traditional literature as a remedy for treatment of diabetes and it is believed that the antihyperglycemic effect of aqueous extract of
C. tetragonoloba beans may be due to presence of tannins, coumarin and flavonoids. ${ }^{10}$

However, there is not much data available on botanical standardization of the plant. In view of this Pharmacognostical standardization on the basis of microscopical studies like histochemical studies with different chemicals have been reported. The study was carried out to ascertain the diagnostic characters through pharmacognostical tools which will be beneficial for the identification of the genuine crude drug.

\section{MATERIALS AND METHODS}

\section{Plant Material}

The fresh pods of Goraksha \{Cyamopsis tetragonoloba (L.) Taub.\} were collected from different vegetable markets of Bangalore (K. R. Puram, Krishna Rajendra and Jayanagar vegetable markets) and the plants were identified with help of Bangalore Flora and from survey of Medicinal plant unit, NADRI, Bangalore and processed in the form of Herbarium, and deposited in RRCBI Herbarium Bangalore for the future reference with voucher specimen no. 12362.

\section{Microscopic analysis}

The pods were soaked in $70 \%$ alcohol for 24 hours, and free hand sections were taken, cleared with chloral hydrate solution and water, stained with different staining reagents according to the standard prescribed methods. Photomicrographs were captured with Cat cam camera. Further pods were also shade dried and powdered for powder microscopy. Powder studies were also carried out by following the standard methods. ${ }^{11,12}$

\section{Micrometric and Histochemical Studies}

Micrometric details of pods were carried out and the measurements were recorded with the help of cat cam software and histochemical 
studies were conducted by using different reagents as per the standard methods. ${ }^{13}$

\section{Physico-chemical analysis}

Physico-chemical analysis such as ash values, extractive values, were carried out according to the standard procedures prescribed in Ayurvedic Pharmacopeia of India.

\section{Preliminary phytochemical analysis}

Preliminary Phytochemical screening was carried out for different extracts by using standard procedures. ${ }^{12,14}$

\section{Thin Layer Chromatography (TLC)}

Shade dried pods coarse powder was extracted with petroleum ether, chloroform and methanol at room temperature with the help of rotary shaker. TLC studies of these extracts were carried out by using, commercially available precoated silica gel plates at room temperature by following standard procedures. ${ }^{15}$

\section{RESULTS AND DISCUSSION}

\section{Macroscopical characters}

Pods green when fresh and pale green in dry condition, compressed, grooved and fibrous at the edges, mature Pods slightly hard, with prominent seeds, can be easily break up by hand, surface smooth, and winged, 4 angular. Petiole glabrous, fibrous, $0.5 \mathrm{~cm}$ long, with pleasant odour and bitter taste (Figure 1).

\section{Microscopic characters}

The transverse section of the pod showed pericarp layer where exocarp consists of epidermis made up of rectangular shaped parenchyma cells with intercellular spaces covered by thin cuticle with distantly arranged small papillae followed by epidermis, 6-9 layers of lignified stone cells with small lumen and filled with brown cell content of tannin were present. The mesocarp region of the pod ridges showed 15-17 layers of tightly arranged thin walled parenchymatous cells without any intercellular spaces were present. Endocarp region consists of 2 to 4 layers of lignified stone cells with wide lumen (Figure 2).

Seed showed outer integument consists of 1- 2 layers of unevenly thickened row of palisade cells, which are made up of macro sclereids. The palisade layer was followed by a single layer of thick walled sub epidermis arranged by elongated coiled cells with abundant simple starch grains. This was followed by 4 to 6 layers of thin walled tangentially elongated parenchymatous cells with abundant simple rounded starch grains. This is followed by 1to 2 layers of endosperm loaded with oil gloubles and aleurone grains. Endosperm region is followed by cotyledon region made up of many layers of compactly arranged thick-walled parenchymatous cells, encumbered with aleurone grains and oil globules (Figure 3). Micrometric details of pods were carried out and the measurements were recorded in Table 2 .

\section{Powder}

Fruit powder light green in colour with prominent small pieces of fibers, smell agreeable and taste bitter, when observed under the microscope, it showed different fragments of tissues like rectangular epidermal cells covered by a thin cuticle and thin walled parenchymatous cells, endosperm and parenchyma cells in groups, epidermal cells with thin walled tangentially elongated parenchymatous cells, lignified fibers with pits, undulated fibers, macro sclereides, thickened helical xylem vessels, epidermal cells with stomata, pitted xylem vessels, tracheid, single fibers, epidermal cells with stomata, etc. (Figure 4).
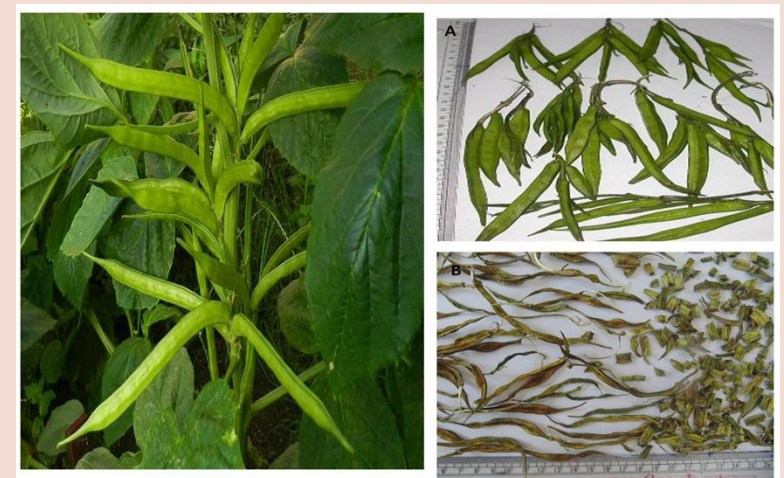

Figure 1: Fresh Plant of Cyamopsis tetragonoloba with pods; A-fresh pods, B-dried pods.

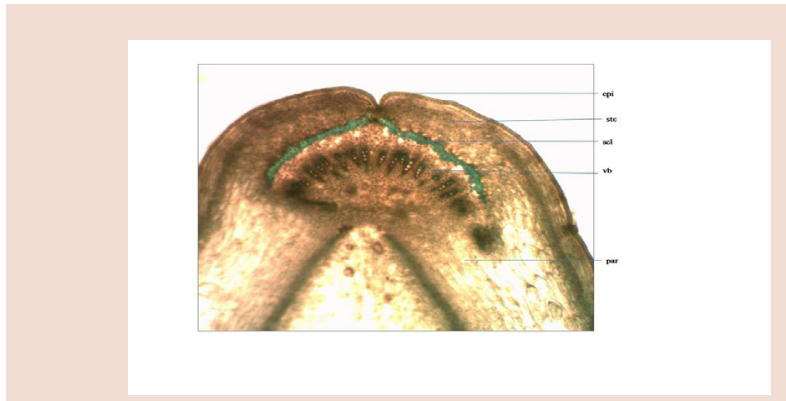

Figure 2: T.S. of Pod 4x; epi-epidermis, scl-sclerenchyma, stc-stone cells, vbvascular bundle, par-parenchyma.

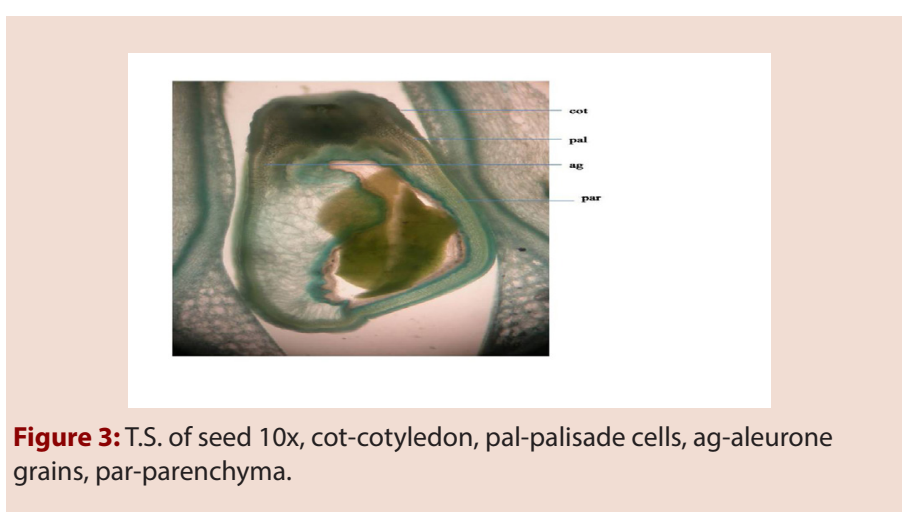

\section{Histochemical Studies of the Fruit}

Histochemical studies of the fruit showed the presence of calcium in epicarp, mesocarp and seed; calcium oxalate, calcium pectate in different regions, protein content, phenols, lignin, starch grains, magnesium, silica contents in different regions of tissues (Figure 5 and Table 1).

\section{Physico-chemical analysis}

Physico-chemical analysis such as loss on drying, total ash, acid-insoluble ash, water \& alcohol soluble extractive values and $\mathrm{pH}$ of $5 \%$ aqueous solution were carried out according to the standard procedures and the results were recorded in Table 3 and 4 .

\section{Preliminary phytochemical analysis}

Preliminary phytochemical screening was carried out for different extracts by using standard procedures and the results were recorded in Table 5. The result indicated the presence of tannins, saponins which 


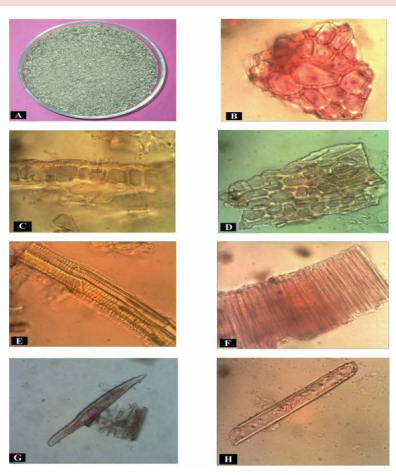

Figure 4: Powder studies: A. Powder; B. Group of Parenchyma cells 40x; C. Epidermal cells covered with thin cuticle10x; D. Epidermal cells with stomata 40x; E. Thickened helical Xylem vessels; F. Macro sclereides 40x; G. Single fiber and parenchymatous cells 40x; H. Single Tracheid 40x.

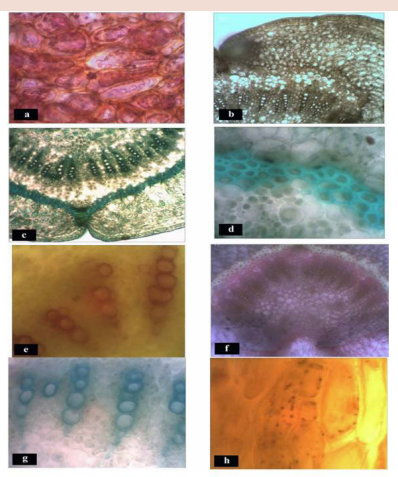

Figure 5: Histochemical studies: $\mathbf{a}$. Calcium oxalate contents 40x; b. Calcium contents in seed 10x; c. Protein contents; $\mathbf{d}$. Phenol contents 10x; e. Lignin contents in vascular bundles 40x; f. Magnesium contents; g. Phenol contents in vascular bundle region; $\mathbf{h}$. Starch contents $40 x$.

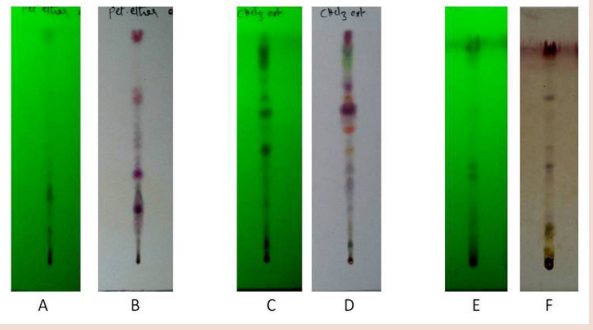

Figure 6: TLC of Cyamopsis tetragonoloba (pods): A \& B-Pet. Ether extract UV254 and After spraying; C \& D- Chloroform extract UV-254 and after spraying; E \& F-Methanol extract UV-254 and after spraying.

may be considered as an indicative of its antidiabetic potential as it was claimed by previous researchers that these phytoconstituents may be responsible for the antihyperglycemic effect of aqueous extract of C. tetragonoloba.

\section{Thin Layer Chromatography (TLC)}

Shade dried pods coarse powder was extracted with petroleum ether, chloroform and methanol with rotary shaker. TLC studies of these extracts were carried out by using, commercially available precoated plates at room temperature by using the mobile phase toluene: hexane: ethyl acetate- 6:3.5:0.5 for petroleum ether extract; Toluene: Ethyl acetate: Chloroform- 6:3.5:0.5for chloroform extract and ethyl acetate: methanol: water- 7.7:1.5:0.8 for methanol extract. The Rf values for different extracts were found as follows:

Petroleum ether extract-Under UV-254: 0.14, 0.31., after spraying with Anisaldehyde-Sulphuric acid $\left(\mathrm{H}_{2} \mathrm{SO}_{4}: 0.14,0.24,0.40,0.55,0.725\right.$. Chloroform extract- under UV-254: $0.26,0.50,0.675,0.725,0.81,0.88$, 0.94 , after spraying with anisaldehyde-sulphuric acid: $0.24,0.35,0.41$, $0.50,0.59,0.675,0.725,0.78,0.88,0.94$. Methanol extract-under UV-254: $0.375,0.44$., after spraying with anisaldehyde-sulphuric acid: $0.16,0.44$, 0.525 and 0.725 (Figure 6).

\section{DISCUSSION}

Goraksha - Cyamopsis tetragonoloba (L.) Taub is found throughout India as a cultivar for its pods and for the source of guargum. Fruit decoction is drunk or fried as a curry or chutney and taken for 40 days is used for diabetes disease, fruit fried with ghee are given to get relief from general weakness during the disease. ${ }^{16}$ Pods are used for cooling, laxative digestive, appetiser, tonic and galactagogue, constipation, dyspepsia, anorexia, agalactia, nyctalopia and vitiated conditions of pitta. ${ }^{17}$ Guar gum is used as a laxative. It is also used for treating diarrhoea, irritable bowel syndrome (IBS), obesity, and diabetes; for reducing cholesterol; and for the prevention of atherosclerosis. In foods and beverages, guar gum is used as a thickening, stabilizing, suspending, and binding agent. Guar gum is widely used as an excipient specifically as binding agent in tablets, and as a thickening agent in lotions and creams. ${ }^{18}$ The gum is used as a laxative and appetite depressant and in peptic ulcer, seeds are rich in protein and can be used for human consumption and for medicinal purposes to cure sprains and swellings, boiled seeds as poultice in plague, enlarged liver, head-swellling due to broken bones etc. The meal obtained as by-product during gum manufacture is also rich in crude protein and essential amino acids and it can be serve as a nutritious feed for cattle, toxic constituents present in meal should be inactivated by appropriate heat treatment. The gum obtained from seed is useful in paper manufacturing, oil-well drilling, mining industry, explosives, pharmaceuticals, cosmetics etc. ${ }^{1}$

The study resulted with the outcome of some basic data regarding the genuine crude drug. Pods pale green in dry condition, fibrous at the edges, microscopically it revealed the presence of uniseriate warty trichomes in the outer most layer of epidermis, macrosclereids in the outermost layer of cotyledon region, lignified polygonal stone cells with wide lumen, in the distal end of the fruit, Rubiaceous type of stomata in the surface view of the epidermal region and presence of abundant fibers in the powder. Histochemically pods showed the presence of phenols, protein, calcium oxalate, magnesium, starch, cellulose, calcium pectate, lignin, sulphated muco polysaccharides, tannin, silica contents in different locations. Qualitative phytochemical studies revealed the presence of alkaloids, carbohydrates, phenols, proteins, starch, tannins and absence of flavanoids and resins.

\section{CONCLUSION}

Pharmacognostical studies carried out with different parameters on Goraksha pods helps in utilizing as a potent herbal ingredient for diabetes along with its important nutrients. Further studies also help in preservation of health, traditional system, therapeutics and revalidation.

\section{ACKNOWLEDGEMENT}

We are highly thankful to Central Council for Research in Ayurvedic Sciences (CCRAS), Ministry of AYUSH, 
Table 1: List of stains and reagents used for the analysis of various histochemicals in different regions of fruit

\begin{tabular}{|c|c|c|c|}
\hline Stain/Reagent & Histochemical & Result & Locality of the cells \\
\hline ТВO & Poly Phenols & $\begin{array}{l}\text { Cells contents turn } \\
\text { turquoise green to blue } \\
\text { green colour. }\end{array}$ & Sclerenchyma cells and Vascular bundles. \\
\hline Fast green & Protein & $\begin{array}{l}\text { Proteins appear bright } \\
\text { green. }\end{array}$ & $\begin{array}{c}\text { Cuticle and Sclerenchyma cells and Vascular } \\
\text { bundles. }\end{array}$ \\
\hline $\begin{array}{l}10 \% \text { Urea, Acetic acid, } \\
\text { Sodium Nitrite mixture } \\
\text { (Nitroso reaction). }\end{array}$ & Phenol & $\begin{array}{l}\text { Phenol substance will turn } \\
\text { into cherry red colour. }\end{array}$ & Sclerenchyma cells and Vascular bundles. \\
\hline $\begin{array}{l}\text { Alkaline pyrogallol } \\
\text { method }\end{array}$ & Calcium & Yellowish brown colour. & $\begin{array}{l}\text { Epidermis, trichome, parenchyma cells in the } \\
\text { hypodermis, cell walls of vascular bundles, } \\
\text { cell walls of Sclerenchyma cells, Cotyedon } \\
\text { portion. }\end{array}$ \\
\hline Silver hydrogen peroxide & Calcium oxalate & Balck in colour. & $\begin{array}{l}\text { Calcium oxalate crystals in the distal end of } \\
\text { the fruit. }\end{array}$ \\
\hline Titian yellow & Magnesium & Brick red 7 colour. & $\begin{array}{l}\text { hypodermis cells, Sclerenchyma cells, } \\
\text { Vascular bundles in distal end of fruit. }\end{array}$ \\
\hline Methyl red & Silica & Yellowish orange. & $\begin{array}{l}\text { Cuticle, Sclerenchyma cells, Vascular bundles } \\
\text { and cotyledon portion. }\end{array}$ \\
\hline $\begin{array}{l}\text { Iodine-potassium iodide } \\
\text { reaction }\end{array}$ & Starch & Blue to black in colour & $\begin{array}{l}\text { Starch grains in the hypodermis of } \\
\text { parenchyma cells and distal end of fruit } \\
\text { parenchyma cells. }\end{array}$ \\
\hline $\begin{array}{l}\text { Tannic acid-ferric } \\
\text { chloride method }\end{array}$ & Calcium pectate & Blue to black in colour & $\begin{array}{l}\text { Epidermal cells, parenchyma cells in the } \\
\text { hypodermis, Sclerenchyma cells, , vascular } \\
\text { bundles and cotyledon portion }\end{array}$ \\
\hline Phloroglucinol method & Lignin & Red in colour. & Sclerenchyma cells and vascular bundles. \\
\hline $\begin{array}{l}\text { Sulphated muco } \\
\text { polysaccharides }\end{array}$ & ТВО & $\begin{array}{l}\text { Pink to reddish purple } \\
\text { colour. }\end{array}$ & $\begin{array}{l}\text { The cell wall of phenolic content cells are } \\
\text { become change to reddish purple color. }\end{array}$ \\
\hline Ferric chloride method & Tannin & Black in colour. & $\begin{array}{l}\text { Almost present all parts of the body and rich } \\
\text { in hypodermis and cotyledon portion. }\end{array}$ \\
\hline
\end{tabular}

Table 2: Micrometric details of Fruit

\begin{tabular}{ccccc}
\hline $\begin{array}{c}\text { Type of Cell } \\
\text { (Measurements are average of } 75 \\
\text { readings) }\end{array}$ & $\begin{array}{c}\text { Minimum } \\
\text { Measurements in } \mu \mathrm{m}\end{array}$ & $\begin{array}{c}\text { Maximum } \\
\text { Measurements in } \mu \mathrm{m}\end{array}$ & $\begin{array}{c}\text { Average with standard } \\
\text { Error } \\
\text { Measurements in } \mu \mathrm{m}\end{array}$ & $\begin{array}{c}\text { Standard } \\
\text { deviation in } \mu \mathrm{m}\end{array}$ \\
\hline $\begin{array}{c}\text { Epidermal cell width } \\
\text { parenchyma cells width }\end{array}$ & 54.23 & 90.43 & 69.18 & 11.49 \\
Sclerenchyma cells width & 72.72 & 277.77 & 157.85 & 52.71 \\
Sub epidermis & 38.01 & 101.12 & 63.20 & 18.03 \\
Cotyledon length & 242.3 & 389.08 & 313.19 & 64.73 \\
Cotyledon width & 904.21 & 1100.92 & 981.17 & 92.09 \\
\hline
\end{tabular}

Table 3: Physicochemical parameters

\begin{tabular}{cc}
\hline Name of the parameter & Values (\%) w/w \\
\hline Description & Light green coarse powder \\
Foreign matter & Less than $1.0 \%$ \\
$\mathrm{pH}(5 \%$ w/v aq. solution $)$ & 6.45 \\
Loss on drying at $105^{\circ} \mathrm{C}$ & 11.09 \\
Total ash & 5.16 \\
Acid-insoluble ash & 0.26 \\
Water-soluble extractive & 28.13 \\
Alcohol-soluble extractive & 7.85 \\
\hline
\end{tabular}


Table 4: Extractive values by Soxhlet extraction

\begin{tabular}{cc}
\hline Solvent & Values (\%) w/w \\
\hline Petroleum ether $\left(40-60^{\circ} \mathrm{C}\right)$ & 0.55 \\
Chloroform & 8.63 \\
Ethanol & 11.01 \\
\hline
\end{tabular}

Table 5: Preliminary Phytochemical tests for Cyamopsis tetragonoloba pods

\begin{tabular}{ccc}
$\begin{array}{c}\text { Natural product } \\
\text { group }\end{array}$ & Test for natural products & $\begin{array}{c}\text { Presence (+)/ Absence } \\
(-)\end{array}$ \\
\hline Alkaloids & (a)Dragendorf's test & $++\mathrm{ve}$ \\
& (b) Hager's test & $+\mathrm{ve}$ \\
& (c) Mayers's test & $+\mathrm{ve}$ \\
& (d) Wagner's test & $++\mathrm{ve}$ \\
Carbohydrates & (a)Anthrone test & $+\mathrm{ve}$ \\
& (b) Benedict's test & $++\mathrm{ve}$ \\
Flavonoids & (c) Fehling's test & $++\mathrm{ve}$ \\
Phenols & (d) Molisch's test & $++\mathrm{ve}$ \\
& & $-\mathrm{ve}$ \\
Proteins & (a) Ferric chloride test & $+\mathrm{ve}$ \\
& Lead acetate test & $+\mathrm{ve}$ \\
Saponins & Biuret's test & $++\mathrm{ve}$ \\
Starch & Millon's test & $++\mathrm{ve}$ \\
Steroids & & $++\mathrm{ve}$ \\
Tannins & Salkowski reaction & $+\mathrm{ve}$ \\
Resins & (a) Ferric chloride test & $+\mathrm{ve}$ \\
& (b) Lead acetate test & $++\mathrm{ve}$ \\
& & $++\mathrm{ve}$ \\
& & $-\mathrm{ve}$ \\
\hline
\end{tabular}

New Delhi, for the sanction of the project and for providing the facilities to carry out the work successfully.

\section{CONFLICT OF INTEREST}

The author declare no conflict of interest.

\section{REFERENCES}

1. Anonymous. The Wealth of India, First Supplement series (Raw Materials) Vol.2, National Institute of Science communication \& Information Resources, CSIR, Dr. K.S. Krishnan marg, New Delhi India. 2001;297-317.

2. Anonymous. Reviews on Indian Medicinal Plants, Vol.8, Medicinal Plants Unit, Indian Council of Medical Research, Ansari nagar, New Delhi, India. 2009;461-77.

3. Kirtikar KR, Basu BD. Indian medicinal plants, Vol. 1. Dehradun: Bishen Singh Mahendra Pal Singh; 1993. p.706.

4. Sharma PV, 2000 (Reprint), Dravyaguna Vignana, vol.3, Chaukambha Bharathi Academy, Varanasi, Tpg. 344, p. 213-4

5. Pande S, Platel K, Srinivasan K. Anti hypercholesterolaemic influence of dietary tender cluster beans (Cyamopsis tetragonoloba) in cholesterol fed rats. Indian J Med Res. 2012;135(3):401-6.

6. Krishnaiaiah TSR, Latha K, Rao N, Karthikeyan L, Bhaskar P, Satanarayana V. Development of colon targeted oral guar gum matrix tablets at albendazole for the treatment of helminthiasis. Indian Journal of Phyto Pharmaceutical Sciences. 2003;65(4):378-85.
7. Bhandari U, Grover JK, Sharma JN. Effect of indigenous drugs an changes in morphology and choloester levels of arota in early arthrosclerotic progression: A comparative experimental study. Hamdard Medicus. 1998:41(4):56-9.

8. Bhandari $U$ \& Shrma $J$ N, Effect of petroleum ether extract of guar gum in streptozotocin-induced hyperglycemic rats, Pharma Biol. 1999;37(3):248.

9. Rahmaullah S, Al-yahya MA, Al-Said MS, Taragan KVAH, Mossa JS. Gastric ulcer and Cytoprotective effects of Cyamopsis tetragonaloba (guar) in rats. International Journal of Pharmacognosy.1994;32(2):163-70.

10. Mukhtar HM, Ansari SH, Ali M, Bhat ZA, Naved T. Effect of aqueous extract of Cyamopsis tetragonoloba L. beans on blood glucose level in normal and alloxane induced diabetic rats. Indian Journal of Experimental Biology. 2004 42(12):1212-5

11. Trease GE \& Evans WC. Pharmacognosy. 12 ${ }^{\text {th }}$ Edition, Bailliere Tindall, A division of Cassell Ltd., Eastbourne BN. 2130N, 1983;17-63.

12. Anonymous. Quality Control Methods for Medicinal Plant Materials, World Health Organization (WHO), Geneva. 1998.

13. Krishanmurthy KV. Methods in Plant Histochemistry. Madras: S.Vishwanathan (Printers \& Publishers) Private Limited. 1988.

14. Anonymous. Physico-chemical standards of Unani formulations, Part-IV, Central Council for Research in Unani Medicine (CCRUM), Dept. of AYUSH, M/o Health \& Family Welfare, Govt. of India, New Delhi. 2006;157-60.

15. Sethi PD. High Performance Thin Layer Chromatography (HPTLC), $1^{\text {st }}$ edition, CBS Publishers \& distributors, New Delhi, India. 1996;1-74.

16. Irfan Ali Khan, AtiyaKanum. Antidiabetic plants of India. Hederabad: Ukaaz Publications. 2005

17. Orient longman. Indian medicinal plants. A compendium of 500 species. Chennai: 
PICTORIAL ABSTRACT

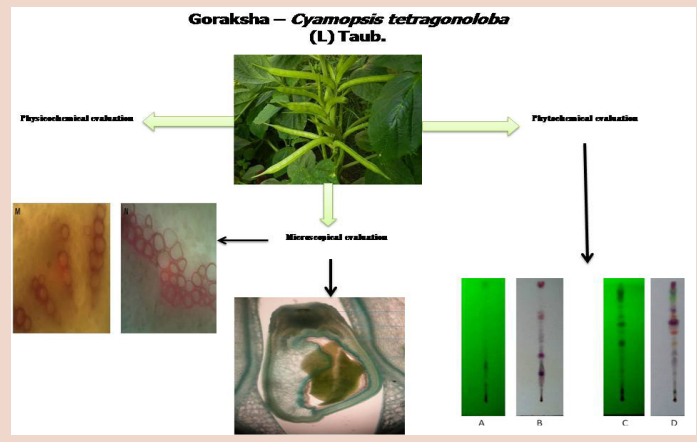

\section{SUMMARY}

- The different standardization parameters studied are very useful to establish the Pharmacopoeial standards which is need of the hour not only for the survival and encouragement of the age old traditional systems of medicine but also in the view of the fact that these systems are attaining Global importance.

- The study resulted with the outcome of some basic data regarding the genuine crude drug. Pods pale green in dry condition, fibrous at the edges, microscopically it revealed the presence of uniseriate warty trichomes in the outer most layer of epidermis, macrosclereids in the outermost layer of cotyledon region, lignified polygonal stone cells with wide lumen, in the distal end of the fruit, Rubiaceous type of stomata in the surface view of the epidermal region and presence of abundant fibers in the powder.

- Histochemically pods showed the presence of phenols, protein, calcium oxalate, magnesium, starch, cellulose, calcium pectate, lignin, sulphated muco polysaccharides, tannin, silica contents in different locations.

- Qualitative phytochemical studies revealed the presence of alkaloids, carbohydrates, phenols, proteins, starch, tannins and absence of flavanoids and resins.

- The studies carried out with different parameters contribute towards utilizing Cyamopsis tetragonoloba (L.) Taub. as a potent herbal ingredient and nutritional supplement for Diabetes and other ailments.

\section{ABOUT AUTHORS}

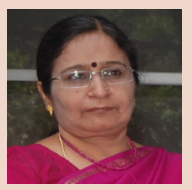

Dr. Shantha T R: Is working as Research officer (Botany) at Drug Standardization Research Unit of Regional Ayurveda Research Institute for Metabolic Disorders, Ashoka pillar, Jayanagar, Bengaluru (CCRAS, Min. of AYUSH, Govt. of India). She is working in the area of Pharmacognosy since 34 years. She has published more than 75 Research papers in National \& International peer reviewed Journals and carried out Pharmacognostical studies on more than 255 medicinal plant drugs and contributed to Ayurvedic Pharmacopeia of India. She has obtained her Ph.D degree in the year 1996 from University of Mysore, India. She is a recognised guide for Ph.D, under University of Mysore, Mysore. 